\title{
Konkurence mezi školami a výsledky žáků v České republice: pohled zblízka na šetření PISA 2012
}

\section{Dominik Dvořák, Jana Straková}

\begin{abstract}
Abstrakt: Reformy založené na zavádèni tržních principư do vzdělávání zatím spiše zklamaly očekáváni, že povedou k celkovému zlepšeni vzdèlávacich výsledkü žákü. Mezinárodni šetreni PISA 2012 tento poznatek rovněž potvrdilo. Avšak v prípadě České republiky byly publikovány výsledky uvádèjici, že i po zohlednèni socioekonomických a demografických rozdilu mezi žáky a dalšich relevantnich faktorü na úrovni škol dosahuji lepšich výsledkủ v matematice žáci $v$ tèch školách, které jsou vystaveny větši lokálni konkurenci. Náš ćlánek predstavuje kritickou revizi těchto výsledkü. Vyšli jsme ze stejných datových souborů z šetreni PISA a použili jsme dvouúrovñové modely, kde prvni úroveň byla žákovská a druhá školni. Pokud model (na rozdil od postupu uplatnèného autory šetřeni PISA) zohledňoval skutečnost, že ve vzorku jsou zastoupeny základni školy, víceletá gymnázia a středni školy, pak zdánlivý účinek konkurence mezi školami vymizel. Konkurence mezi školami jednoho typu tedy ani $v$ České republice nevede $k$ lepšim znalostem a dovednostem žákù $v$ matematice.
\end{abstract}

Klíčová slova: volba školy, konkurence mezi školami, výsledky žákü, matematika, Česká republika, PISA.

Možnost rodičů volit konkrétní školu, v níž bude dítě plnit povinnou školní docházku, a s tím související konkurenční „boj“ škol o žáky se v posledním zhruba čtvrt století staly důležitým rysem vzdělávacích systémů mnoha zemí (van Zanten, 2009). Volbou školy se proto v poslední době i v České republice zabývalo více pra- cí, které zkoumaly postoje a chování rodičů, resp. sociální důsledky tohoto jevu (např̀. vznik etnicky segregovaných škol). Šetření PISA však skýtá možnost sledovat i pedagogické dopady konkurence mezi školami, jimiž by podle některých předpokladů měla být rostoucí efektivita vyučování vedoucí $\mathrm{k}$ lepším znalostem a dovednostem žáků

\footnotetext{
${ }^{1}$ Výzkum byl podpořen projektem GA ČR Vztahy mezi dovednostmi, vzděláváním a výsledky na trhu práce: longitudinální studie (P402/12/G130).

${ }^{2}$ Autoři děkují dr. Josefu Baslovi (ČŠI) za poskytnutí některých dat a dr. Jaroslavě Simonové (ÚVRV PedF UK) za cenné připomínky $\mathrm{k}$ první verzi rukopisu; rovněž děkujeme oběma recenzentům za konstruktivní zpětnou vazbu.
} 
v těch školách, které „bojují o své zákazníky“. V tomto textu se zabýváme kritickou analýzou publikovaných závěrů (OECD, 2013, 2014b), naznačujících pro Českou republiku pozitivní vliv konkurence mezi školami na jejich efektivitu/výsledky.

\section{RODIČOVSKÁ VOLBA}

\section{A KONKURENCE MEZI ŠKOLAMI}

V minulých dvou stoletích státy přebíraly odpovědnost za zajištování některých služeb pro své občany, protože cítily potřebu kompenzovat nevýhody trhu $\mathrm{v}$ těchto oblastech. $\mathrm{V}$ neposlední řadě šlo o počáteční vzdělávání. Nejprve $\mathrm{v}$ rozvinutých, později i v rozvojových zemích tak bylo díky kvantitativní expanzi veřejného sektoru dosaženo prakticky univerzální dostupnosti primárního a v rostoucí míře i sekundárního vzdělávání. ${ }^{3}$ Novým problémem se však stala nestejná kvalita takto dostupných škol. Přitom kvalita vzdělávání může být pro osvojení potřebných znalostí a dovedností důležitější než jeho délka (Gillies, 2010). Řešení problému kvality škol část odborníků, politiků i rodičů očekává od vstupu/návratu dalších aktérů do oblasti poskytování vzdělávání a od jejich soutěže. ${ }^{4}$ Situace se tedy obrací a v posledních zhruba dvaceti pěti letech řada zemí provádí reformy vycházející z předpokladu, že selhávání státu jako poskytovatele vzdělávání bude $\mathrm{v}$ oblasti kvality kompenzovat trh.

\subsection{Podoby konkurence mezi školami}

Tržní mechanismy ve vzdělávání jsou propagovány neoliberály, kteří věríi, že konkurence $e^{5}$ vyvolá tlak na špatné školy a povede bud' $\mathrm{k}$ jejich zlepšení, nebo zániku. Průkopníkem této myšlenky a zakladatelem nadace pro posílení trhu ve vzdělávání byl ekonom a pozdější nositel Nobelovy ceny Milton Friedman. ${ }^{6}$ Rozšíŕená možnost volby školy má rovněž zvýšit pravděpodobnost, že si žáci (resp. jejich rodiče) vyberou školu, jež nejlépe odpovídá žákovým potřebám a preferencím a kde tedy budou dosahovat optima jeho výsledky i spokojenost (Gibbons, Machin \& Silva, 2008). Konečně posílení role rodičů jako „zákazníkü“ vzdělávacího systému podporují i ti, kdo volbu školy považují za základní lidské právo (Straková \& Simonová, 2015) a kdo si myslí, že bohatí lidé možnost volby mají vždycky, proto by ji měli dostat i ostatní.

\footnotetext{
3 Otázka cílů je ovšem složitější, konkrétní aktéři (politici, úřednictvo) při budování státního vzdělávacího systému mohli sledovat i svou agendu v podobě sekularizace, indoktrinace apod. Navíc v některých případech byli již před vznikem veřejného vzdělávání nestátní poskytovatelé překvapivě efektivní při zajištování masového vzdělávání (West, 2009, s. 365).

${ }^{4}$ Druhou dominantní, do určité míry komplementární strategií reformy s cílem zvýšení kvality je na testech založená akontabilita (Bruns, Filmer \& Petrinos, 2011). Oba př́stupy se shodují zejména v potřebě veřejně dostupných informací o výsledcích žáků (West \& Peterson, 2006) a podpoře autonomie jednotlivých škol.

${ }^{5}$ Výrazy konkurence a soutěž užíváme v textu jako ekvivalenty.

${ }^{6}$ Friedman navrhoval zásadně přehodnotit úlohu státu, i ve vzdělávání vrátit iniciativu nestátním subjektům a státu ponechat především kontrolní roli, popr. financování některých aktivit (Simonová, 2015b).
} 
Pokud jde o samotnou terminologii, představa (počátečního) vzdělání jako zboží může být pro řadu lidí obtížně přijatelná. Zdá se, že výbèr školy zní lépe než trh se vzdělávánim, i když přinejmenším části zastánců volby školy přesně o tržní mechanismy jde. $\mathrm{V}$ současnosti tak můžeme vzrůstající soutěž mezi školami vnímat $\mathrm{v}$ souvislosti $\mathrm{s}$ jinými procesy probíhajícími ve školství (van Zanten, 2005) - posilováním autonomie a profilace škol, přechodem od hierarchického $\mathrm{k}$ heterarchickému uspořádání $\mathrm{s}$ řadou různých aktérů podílejících se na poskytování a správě vzdělávání, nástupu takzvané nové dobročinnosti (Ball, 2008), kde se bohulibé cíle při zakládání nových či restrukturalizaci stávajících škol stávají nástrojem budování image komerčních firem nebo přímo novou príležitostí pro generování zisku.

Podpora volby školy ve zde sledovaném smyslu tedy může směřovat ke dvěma různým př́padům konkurence mezi školami podle toho, kdo jsou jejich zřizovatelé (Hess, 2009): 1. Posílení práva rodičů vybírat si v rámci sítě veřejných škol se snaží donutit veřejné školy, aby mezi sebou soutěžily a aby se více chovaly jako podnikatelské subjekty. Zde stát může např. jít cestou odstranění administrativních překážek volby školy, ale třeba i dotováním žákovského jízdného (které pomáhá překonat ekonomická omezení rodin). 2. Podpora nestátních zřizovatelů chce do sektoru vzdělávání přilákat nové akté- ry, tedy nové lidské i finanční zdroje. Současně se tak posiluje soutěž mezi školami veřejnými na straně jedné a soukromými (církevními) na straně druhé. Např́íklad vzdělávací kupony (vouchery) umožňují v některých zemích žákům využít veřejných prostředků pro studium na soukromých a církevních školách, které by jim jinak byly finančně nedostupné. Dřívější konzervativní vlády ve Spojeném království systémem státních stipendií (Assisted Places Scheme) zvyšovaly př́stup neprivilegovaných žáků do privátních škol nezávislých na státu, aby tím ekonomicky i morálně podporovaly systém elitních škol (Walford, 1996). V poslední době řada zemí navíc experimentuje se systémem poloveřejných škol, kde školu provozuje nestátní subjekt (komerční či nekomerční), ale podstatnou nebo celou výši provozních nákladů nese stát (svobodné školy ve Švédsku, charter schools v USA, akademie ve Spojeném království aj.).

Tradičně je rozsáhlá možnost volby mezi státní a nestátní školou např. v Belgii a Nizozemsku, kde církevní školy, popř. i jejich ucelené systémy existovaly vedle státních škol již před vlnou zájmu o tržní př́istupy ve vzdělávání díky zájmu rodičů (často nábožensky motivovanému), kteří chtěli mít možnost více ovlivňovat obsah a podobu výuky nebo kulturu školy. ${ }^{7}$ Významnou roli privátní poskytovatelé měli již dříve také $\mathrm{v}$ zemích, kde se stát ujal organizace vzdělávání poměrně pozdě (některé anglosaské země) a sít škol se vy-

\footnotetext{
${ }^{7}$ Nábožensky či nacionálně motivované skupiny se snažily vytvářet na státu nezávislé struktury edukačního působení dokonce i v komunistických zemích, kde si stát monopolizoval školní vzdělávání (Dvořák, 2007).
} 
tvářela „zespodu“ iniciativou různých aktérů. Za specifický př́ípad uplatnění práva na volbu školy můžeme považovat domácí vzdělávání. Naproti tomu v německy mluvících zemích vzdělávací politika nekladla takový důraz na tržní principy (Altrichter et al., 2011).

V diferencovaných vzdělávacích systémech, jako je český, existuje již na úrovni nižšího sekundárního vzdělávání ještě konkurence mezi různými typy institucí - např́klad mezi základními školami a víceletými gymnázii (viz část 1.3).

\subsection{Efekty konkurence mezi školami}

Jak jsme uvedli, primární motivací zavádění tržních mechanismů do školství je snaha zvýšit kvalitu práce škol prostřednictvím soutěže mezi nimi a lepší alokace žáků. Kvalitu školy však lze pojímat mnoha odlišnými způsoby, proto se řada autorů zaměřuje na poměrně úzce vymezenou efektivitu, chápanou jako úroveň vzdělávacích výsledků $\mathrm{v}$ předmětech tvořících jádro kurikula (achievement), v poslední době také na míru dokončování školy (attainment). Diskuse o tom, zda soutěž mezi školami vede $\mathrm{k}$ zlepšení výsledků žáků, ${ }^{8}$ je velmi obsáhlá a řada autorů dosavadní poznatky považuje za rozporné (např. Berends, 2015; Gibbons et al., 2008; Hess, 2009; OECD, 2013; Póder \& Kerem, 2012). I pokud by se ukázalo, že žáci v nových školách, které vstupují na trh jako alternativa stávajících, dosahují lepších výsledků, může to pouze znamenat, že alternativní školy přilákaly lepší žáky z běžných škol (Ježková, Dvořák \& Chapman, 2010, s. 203-204) a že problém neefektivity se jen přesunul do jiných škol. Musí nás zajímat, zda tam, kde je vyšší konkurence mezi školami, se zlepšují celkové průměrné výsledky žáků všech škol (bud'v celé zemi, nebo na určitém lokálním vzdělávacím trhu).

Proto je otázka volby školy také předmětem zájmu výzkumu PISA a do posledních cyklů byly zahrnuty otázky, které zjištovaly, jak velké konkurenci jsou jednotlivé školy vystaveny. Zjištění z nejnovějšího šetření PISA 2012 byla shrnuta do následujících tezí (OECD, 2014b): Ve většině zemí účastnících se šetření PISA 2012 se více než polovina patnáctiletých žáků (na něž studie PISA cílí) vzdělává ve školách, které si konkurují $s$ jinou školou nebo školami ve snaze získat žáky z téže sídelní oblasti. Avšak při analýze $\mathrm{v}$ rámci jednotlivých vzdělávacích systémů se neprokazuje, že by míra soutěže o žáka ovlivňovala efektivitu škol. Důvodem může být, že akademický výkon škol je sice pro rodiče při výběru školy významný, často jim ale ještě více jde o bezpečí dětí, prostředí školy a o její pověst; pro děti samé jsou často velmi významné vrstevnické vztahy a při výběru škol mají tendenci kopírovat volbu kamarádů. Rodiče berou při výběru školy v potaz i řadu dalších kritérií - pro socioekonomicky znevýhodněné rodiče jsou při výběru školy ve srovnání s efektivitou školy stejně vý-

\footnotetext{
${ }^{8}$ Legitimní jsou také otázky po fiskálních dopadech tržně orientovaných reforem.
} 
znamné nebo dokonce ještě významnější finanční náklady spojené s dojižd'kou do určité školy.

To je ve shodě s dosavadními poznatky (Hess, 2009, s. 508-509), podle nichž žádoucí působení trhu ve vzdělávání komplikuje zejména absence shody o kritériích kvalitní služby, omezená nebo nerovnoměrně prostorově rozdělená kapacita alternativní nabídky, transakční náklady spojené se změnou poskytovatele služby (transfery mezi školami), faktory spojené s cenovou konkurencí (není motivace $\mathrm{k}$ úsporám $\mathrm{z}$ hlediska veřejných zřizovatelů). Prostá myšlenka využití trhu ve vzdělávání má proto řadu kritiků a odpůrců, kteří bud' zpochybňují princip sám, nebo poukazují na jeho vedlejší a nezamýšlené negativní důsledky.

$V$ neposlední řadě je problémem reálného fungování trhu ve vzdělávání zmíněné pokušení škol vybírat si „perspektivnější “ žáky. Mechanismus volby školy totiž může být vždy (i když to oficiálně třeba není př́ípustné) interpretován dvojím způsobem: škola je žáky/rodiči vybírána, ale také si škola žáky/rodiče vybírá (Jennings, 2010). ' Specifická demografická situace (dočasný nadbytek žáků) stejně jako prestiž a získaná pozice $\mathrm{v}$ hierarchii na místním trhu (Nekorjak, Souralová \&
Vomastková, 2011) umožňují škole zpřísnit kritéria přijímání mimospádových dětí (kritéria mohou být nejen akademická, ale i absence problémů v chování - srov. van Zanten, 2009, s. 93). Možnost volby školy a nutnost škol soutěžit o žáky proto zvyšuje sociální segregaci škol, a má tak dopady na spravedlivost vzdělávání a sociální kohezi nebo míru inkluze žáků se speciálními vzdělávacími potřebami (Waitoller \& Thorius, 2015). Při pohledu na země zkoumané ve výzkumu PISA se sice mezi lety 2003 a 2012 nezvýšila míra diferenciace mezi školami podle socioekonomického původu žáků, avšak v roce 2012 bylo méně pravděpodobné, že žáci s odlišnými akademickými schopnostmi a potřebami navštěvují stejnou školu (OECD, 2015).

\subsection{Konkurence mezi českými školami}

V České republice byly krátce po začátku postkomunistické transformace ${ }^{10}$ vytvořeny legislativní podmínky pro soutěž o žáka, tedy kvazitržní prostředí. ${ }^{11}$ Již ve výzkumu provedeném $\mathrm{v}$ polovině devadesátých let minulého století Rabušicovou a Polem (1996a, 1996b) si české školy jasně uvědomují, že se začínají „postupně ocitat $\mathrm{v}$ konkurenčním prostředí

\footnotetext{
${ }^{9}$ Navíc školy spolu soupeří i o další zdroj, jímž jsou dobří učitelé či ředitelé.

${ }^{10}$ Formálně jednotné české základní školství bylo ve skutečnosti i před rokem 1989 do určité míry diferencované díky zřizování škol s rozšriřenou výukou některých předmětů (a naopak speciálních škol), a rodiče tak do určité míry mohli školu pro své děti vybírat (Straková a Simonová, 2015).

${ }^{11}$ Prof. Petr Vopěnka vyprávěl jednomu z autorů, že princip financování škol podle počtu žáků zavedl v době svého ministerského působení z důvodu, který nesouvisel se vzdělávací politikou. Údajně v době rozpadu federace a diskusí o státoprávním uspořádání České republiky zjistil, že na regionální školství v Čechách jsou vynakládány relativně větší prostředky než na Moravě (domníváme se, že kvưli odlišné sídelní struktuře), a bál se, že to bude zneužito politicky.
} 
jiných škol, jež - stejně jako ona sama potřebují dostatek žáků a $s$ nimi přicházejících peněz". V minulé dekádě $\mathrm{k}$ tomu přispěl i prudký pokles celkového počtu žáků, o něž základní školy soutěžily. Tržní princip, kdy žáci přinášejí školám peníze, byl však někde školami vnímán jako „neštastný" krok státu. O několik let později Rabušicová a kol. (2003, s. 112) již konstatují, že ve vztahu rodičů ke škole „drtivou měrou převažuje zákaznický přístup. (...) To znamená, že nejčastěji se na českých školách, alespoň podle vyjádření našich respondentů, můžeme setkat $s$ rodiči zákazníky, kteří volí pro svoje dítě školu záměrně, přejí si, aby jejich děti učili jen ti nejkvalifikovanější učitelé, a také požadují, aby jim škola poskytovala potřebné informace."

Cestou, kterou se snaží od počátku školy přesvědčit rodiče o kvalitě nabízené služby v situaci, kdy u nás neexistují transparentní informace o vzdělávacích výsledcích, se často stává rozšířená nabídka kurikula. Kvantitativní (Straková \& Simonová, 2015), kvalitativní (Dvořák, Starý \& Urbánek, 2015a) i smíšené (Kučerová, Bláha \& Pavlasová, 2015) studie naznačují, že význam výběru škol rodiči stále roste a přestává být záležitostí geograficky či sociálně omezené skupiny obyvatel. Podíl základních škol se soukromým zřizovatelem je sice v České republice relativně nízký (OECD, 2014a), nejde však o jediný ukazatel konkurence mezi školami. V českém vzdělávacím systému dochází $\mathrm{k}$ významné diferenciaci $\mathrm{v}$ rámci systému veřejných škol. Nejedná se jen o systém víceletých gymnázií, ale rovněž o základní školy s rozšířenou výukou cizích jazyků nebo nějakého jiného předmětu, bilingvní výukou a podobně. Přestože tyto školy spadají do kategorie veřejných škol, často jsou nadstandardní služby $\mathrm{v}$ těchto školách poskytovány za úhradu. Zdá se také, že (dočasný) obrat demografických trendů $\mathrm{v}$ posledních letech představuje nový impulz pro vznik soukromých škol, jejichž zřizovatelé pružněji reagují na situaci. Konečně také v České republice jsme zřejmě svědky nástupu „nové dobročinnosti“ a vzniku nestátních škol zřizovaných či podporovaných aktéry jako společnost Scio nebo nadace The Kellner Family Foundation.

V České republice sledovali výzkumníci mechanismy a účinky práva volit školu zejména kvalitativně a z perspektivy etnické diferenciace škol. Nekorjak, Souralová a Vomastková (2011) nebo Kašparová a Souralová (2014) ukázali, jak dochází $\mathrm{k}$ vytváření segregovaných romských a neromských škol. Geografové Kučerová (2012) a Kučerová et al. (2015) sledovali dopad soutěže na strategie venkovských škol i na jejich komunity. Soutěž mezi školami nemusí vést $\mathrm{k}$ zpestření kurikulární nabídky, ale naopak může vést k unifikaci (Adnett $\&$ Davies, 2000) - v českých podmínkách se prostřredkem soutěže často stává rozšířená výuka cizích jazyků, ${ }^{12}$ zejm. angličtiny (Dvořák, Starý \& Urbánek, 2014, 2015b), nikoli úsilí o zlepšení výsledků $\mathrm{v}$ předmětech jako

\footnotetext{
${ }^{12}$ Podobné procesy popsali v Rakousku nedávno Altrichter, Heinrich a Soukup-Altrichter (2014).
} 
čeština a matematika. ${ }^{13}$ Výzkum efektů soutěže mezi školami na výsledky žáků však chybí (asi proto, že v České republice není dostatek srovnatelných dat o výsledcích žáků).

\section{VÝZKUMNÝ PROBLÉM}

Obecně se přepokládá, že pro fungování trhu jsou nezbytné informace, aby se zákazník mohl poučeně rozhodovat. Pokud má volba školy vést $\mathrm{k}$ dosažení vyšší efektivity výuky, rodiče by měli dostávat objektivní data o výsledcích žáků $\mathrm{v}$ různých školách. To se v mnoha zemích realizuje formou plošného testování a zveřejňování výsledků škol. Zpráva z výzkumu PISA 2012 však přinesla paradoxní výsledek. Přestože aktéři českého vzdělávání postrádají zpětnou vazbu v podobě spolehlivých informací o výsledcích jednotlivých škol, OECD uvádí (viz též Prúloha 1), že v Česku je mechanismus konkurence účinný právě v oblasti efektivity: „Pouze v České republice a Estonsku platí, že školy soutěžící s jinými školami v téže oblasti o žáky dosahují v průměru lepších výsledků než školy, které konkurenci vystaveny nejsou, když bereme $\mathrm{v}$ úvahu socioekonomický status žákủ a demografické složení i další charakteristiky škol“" (OECD, 2013, s. 54).

Cílem této práce je porozumět uvedenému překvapivému výsledku týkajícímu se České republiky.

Ve výzkumu PISA je cílová skupina definována nikoli ročníkem školní do- cházky, ale prostřednictvím věku. Cílovou skupinu tvoří všichni žáci, kteří v kalendářním roce testování dosahují 16 let. To znamená, že v České republice do ní patří nejen žáci z různých ročníků, ale dokonce stupňů vzdělání: zhruba polovina testované populace se nachází v posledních ročnících povinného vzdělávání ( $\mathrm{tj}$. $\mathrm{v} 9$. ročníku a $\mathrm{v}$ malé míře rovněž v 7. a 8. ročníku) a zhruba polovina $\mathrm{v}$ prvním ročníku střední školy (10. ročník školní docházky). Skutečnost, že se $\mathrm{v}$ českém datovém souboru nacházejí jak základní školy, tak různé typy středních škol, nebyla při výše prezentované analýze zohledněna. Naším cílem je ověritit, zda efekt konkurence přetrvá i tehdy, když bude typ školy do analýzy zahrnut. Analýza tedy hledá odpověd’ na následující výzkumnou otázku: Vykazuje konkurence mezi školami pozitivni efekt na výsledky vzděláváni patnáctiletých žákủ i po zoblednèni typu školy?

Dalším cílem bylo zjistit, zda, případně jak se faktor konkurence a další faktory na úrovni školy uplatňují v homogennějším souboru škol, tedy konkrétně zda konkurence mezi školami a další školní proměnné pozitivně ovlivňují výsledky vzdělávání patnáctiletých žáků navštěvujících základní školy. Základním školám jsme věnovali speciální pozornost $\mathrm{z}$ důvodu rostoucí diferenciace, která probíhá v systému živelně a není nikterak monitorována. Zatímco u středních škol je výběr, odlišnost a s tím spojená konkurence po-

\footnotetext{
${ }_{13}$ Pravděpodobně se však cizí jazyky přidávají $\mathrm{k}$ základním předmětům, podle nichž jsou vzdělávací výsledy školy hodnoceny, a možná dokonce angličtina z této pozice vytlačuje tradiční dovednosti trivia (Dvořák, Starý \& Urbánek, 2015a).
} 
važována za přirozenou a žádoucí, v rámci sítě základních škol se jedná o relativně nový fenomén, který může mít (a pravděpodobně již má) nepředvídané důsledky. $\mathrm{O}$ povaze těchto důsledků je třeba se co nejlépe poučit. To mimo jiné znamená zjistit, jaké má konkurence mezi základními školami dopady na efektivitu vzdělávání.

\section{DATA, METODY}

K analýzám byly využity české datové soubory z výzkumu PISA 2012 obsahující výsledky žáků a data z žákovských a školních dotazníků. Soubory obsahovaly údaje od 5236 žáků ze 126 základních škol, 57 víceletých gymnázií, 20 čtyřletých gymnázií, 53 středních odborných škol s maturitou a 25 středních odborných učilišt bez maturity. Datové soubory obsahovaly ještě údaje od 91 žáků z 16 praktických a speciálních škol, které jsou uvedeny $\mathrm{v}$ deskriptivní tabulce 1 , avšak v našich analýzách tito žáci dále nebyli zahrnuti. Výběr respondentů probíhal dvoustupňově: nejdříve byly náhodně vybrány školy z databáze všech škol, které navštěvují žáci v definované věkové kategorie, v těchto školách pak náhodně třicet žáků. Aby bylo možno v České republice provádět analýzy vědomostí a dovedností žáků na konci povinného vzdělávání, byl proveden nadvýběr žáků v 9. ročnících ZS a odpovídajících ročnících víceletých gymnázií. Při analýzách byly využívány žákovské váhy, které zohledňují výběr a zachovávají proporce jednotlivých typů škol tak, jak jsou zastoupeny ve vzdělávacím systému.

Efekt školních proměnných na výsledky vzdělávání byl zkoumán prostřednictvím dvouúrovňových modelů, kde první úroveň byla žákovská a druhá školní, stejně jako tomu bylo v modelech OECD. Výpočty byly provedeny $\mathrm{v}$ programu HLM 6.0, který zohledňuje výběr vzorku a umožňuje rovněž správně pracovat $s$ žákovskými skóry. ${ }^{14}$

Jako závislá proměnná figuroval v použitých modelech výsledek z matematiky vyjádřený prostřednictvím pěti plauzibilních hodnot. ${ }^{15} \mathrm{Na}$ žákovské úrovni do modelu vstupoval ještě index kulturního, sociálního a ekonomického statusu (escs), který je standardní součástí datového souboru z výzkumu PISA a je vypočten z proměnných udávajících vzdělání a povolání rodičů a vybavení domácnosti

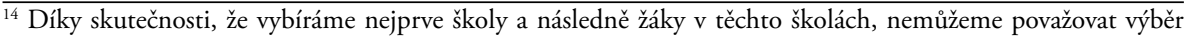
za striktně náhodný. Mezi respondenty existuje větší podobnost, než by existovala, kdybychom prováděli výběr jednostupňově a vybírali respondenty náhodně z celé populace patnáctiletých žáků. Software HLM byl vyvinut speciálně pro práci $s$ víceúrovňovými daty a př̀i výpočtu standardních chyb zohledňuje jejich hierarchickou strukturu. Víceúrovňové modely lze však řádně počítat i v řadě dalších běžně používaných i specializovaných programů. Bližší poučení o víceúrovňovém modelování v pedagogických vědách získá čtenář ve výborném článku Petra Soukupa (Soukup, 2006).

${ }^{15} \mathrm{~V}$ mezinárodním výzkumu PISA jsou výsledky stanovovány prostřednictvím pěti náhodných hodnot z pravděpodobnostního rozdělení žákovské zdatnosti v dané oblasti (plausible values - plauzibilní hodnoty). Statistické výpočty je třeba provádět odděleně s každou hodnotou a výsledky zprůměrovat. Standardní chyba výsledku je pak stanovena z rozptylu výsledků jednotlivých plauzibilních hodnot.
} 
(zjištována je nejen celková majetková situace, ale i vybavení kulturními předměty, knihami apod.).

$\mathrm{Na}$ úrovni školy byly použity následující nezávislé proměnné16:

- KONKURENCE - ve spádové oblasti dané školy je alespoň jedna škola, která se uchází o žáky dané školy. ${ }^{17}$

- DIFERENCIACE - žáci jsou rozdělováni do tříd/skupin podle schopností nebo zaměření. ${ }^{18}$

- RODIČE - očekávání rodičů: souhlas s tvrzením Mnoho rodiču po naši škole neustále vyžaduje, abychom na žáky kladli vysoké nároky a abychom zajistili, že naši žáci budou dosahovat výborných výsledkư. ${ }^{19}$

- VELIKOST - celkový počet žákủ ve škole.

- SBOR - mezinárodní indikátor vytvořený na základě míry souhlasu ředitele s tvrzeními morálka učitelì $v$ naši škole je vysoká, učitelé pracují s nadšsenim, učitelé jsou na školu hrdí, učitelé oceňuji studijni uspěchy žákư. ${ }^{20}$

- VEŘEJNÁ - veřejná škola (vs. soukromá nebo církevní). ${ }^{21}$

- ESCS - index ekonomického sociálního a kulturního statusu agregovaný na úroveň školy.

Dále byly do analýzy zahrnuty čtyři proměnné charakterizující velikost sídla školy:

- NAD_3000 - obec s počtem obyvatel nad 3 tisíce obyvatel,

- NAD_15 000 - obec s počtem obyvatel nad 15 tisíc obyvatel,

- NAD_100 000 - obec s počtem obyvatel nad 100 tisíc obyvatel,

- PRAHA.

Do analýzy základních škol byly zařazeny ještě následující nezávislé proměnné:

- VÝBĚR - žáci jsou do školy vybíráni podle schopností. ${ }^{22}$

\footnotetext{
${ }^{16}$ Jedná se vesměs o proměnné použité $\mathrm{v}$ mezinárodní analýze. $\mathrm{V}$ analýze základních škol byla dále zařazena proměnná charakterizující úsilí ředitele věnované propagaci školy.

${ }^{17}$ Protože se jedná pro naše téma o klíčovou proměnnou (proměnná SC04 ve školním dotazníku), je potřeba si povšimnout přesného znění české verze: Zajimá nás, jaké možnosti mají rodiče při výběru školy pro své děti. Které $z$ následujicich tvrzeni nejlépe vystihuje, jaké možnosti maji rodiče v mistè, kde se nacházi Vaše škola? Ředitel školy při tom vybíral ze tří nabídnutých možností: Ve spádové oblasti naši školy jsou dvě nebo více dalšich škol / ještě jedna dalši školal neni žádná dalši škola, kterése ucházeji o naše žáky. Česká verze tedy nahradila poměrně obecnou formulaci originálního anglického dotazníku „in this area“ konkrétnější „ve spádové oblasti naší školy“. (Pro srovnání - slovenský školní dotazník na odpovídajícím místě užívá „, tejto lokalite sú dve alebo viaceré iné školy, ktoré s nami sútažia o žiakov“.) Nelze vyloučit, že u českého dotazníku došlo k posunu významu, protože v př́padě základních škol by ve spádové oblasti neměla být jiná (veřejná) škola stejného typu nikdy. $V$ této souvislosti je zvláštní, že Česká republika je jediná země OECD, kde na tuto a další otázky školního dotazníku odpovědělo méně než $85 \%$ ředitelů.

${ }^{18}$ Jedná se o školy, které uvedly, že v některých třídách jsou žáci na výuku matematiky rozdělováni podle schopností a/nebo že v různých tř́íách jsou vyučovány obsahové celky s různou obtížností (proměnné SC15 ve školním dotazníku).

${ }^{19}$ Proměnná SC24 ve školním dotazníku.

${ }^{20}$ Proměnná TCMORALE ze školního datového souboru.

${ }^{21}$ Tento indikátor byl využit pouze $\mathrm{v}$ analýze pro patnáctileté žáky navštěvující všechny typy škol. V souboru žáků základních škol bylo žáků nestátních škol př́liš málo.

${ }^{22}$ Proměnná SC32 ve školním dotazníku.
} 
- PROPAGACE - četnost práce ředitele na zlepšování dobrého jména školy (na šestistupňové škále). ${ }^{23}$

\section{VÝSLEDKY}

Nejprve uvedeme několik převážně popisných informací o školami vnímané míre konkurence. Pak predstavíme vý- sledky analýzy vlivu konkurence na výsledky žáků v matematickém testu PISA.

\subsection{Deskriptivní údaje o míře konkurence}

Tabulka 1 uvádí míru řediteli vnímané konkurence podle typu školy. Je zřejmé, že víceletá gymnázia a střední školy pocitují

Tab. 1a. Počty škol ve vzorku PISA, jejichž ředitelé vnímají rozdílnou míru konkurence lokálních škol

\begin{tabular}{|l|c|c|c|c|c|}
\hline \multirow{2}{*}{ Typ školy } & \multicolumn{4}{|c|}{ Počet konkurenčních škol } & \multirow{2}{*}{ Celkem } \\
\cline { 2 - 5 } & dvě a více & jedna & žádná & neuvedl & \\
\hline ŽS & 61 & 20 & 27 & 18 & 126 \\
\hline VG & 42 & 4 & 1 & 10 & 57 \\
\hline $4 G$ & 16 & 0 & 0 & 4 & 20 \\
\hline SOŠ & 41 & 5 & & 7 & 53 \\
\hline SOU & 20 & & 2 & 3 & 25 \\
\hline Spec. & 4 & 3 & 5 & 4 & 16 \\
\hline Celkem & 184 & 32 & 35 & 46 & 297 \\
\hline
\end{tabular}

Poznámka: Cramérovo $V=0,32$

Tab. 1b. Podíly škol ve vzorku PISA, jejichž ředitelé vnímají různou míru konkurence lokálních škol

\begin{tabular}{|l|c|c|c|c|c|}
\hline \multirow{2}{*}{ Typ školy } & \multicolumn{3}{|c|}{ Počet konkurenčních škol } & \multirow{2}{*}{ Celkem } \\
\cline { 2 - 5 } & dvě a více & jedna & žádná & neuvedl & \\
\hline Ž́ & $48 \%$ & $16 \%$ & $21 \%$ & $14 \%$ & $100 \%$ \\
\hline VG & $74 \%$ & $7 \%$ & $2 \%$ & $18 \%$ & $100 \%$ \\
\hline $4 G$ & $80 \%$ & $0 \%$ & $0 \%$ & $20 \%$ & $100 \%$ \\
\hline SOŠ & $77 \%$ & $9 \%$ & $0 \%$ & $13 \%$ & $100 \%$ \\
\hline SOU & $80 \%$ & 0 & $8 \%$ & $12 \%$ & $100 \%$ \\
\hline Spec. & $25 \%$ & $19 \%$ & $31 \%$ & $25 \%$ & $100 \%$ \\
\hline
\end{tabular}

${ }^{23}$ Proměnná SC3401 ve školním dotazníku. 
Tab. 2. Podíl základních škol ve vzorku PISA, jejichž ředitelé vnímají konkurenci lokálních škol, podle velikosti sídla školy (počty škol a řádková procenta)

\begin{tabular}{|l|c|c|c|c|c|}
\hline \multirow{2}{*}{ Velikost obce } & \multicolumn{3}{|c|}{ Počet konkurenčních škol } & \multirow{2}{*}{$\begin{array}{c}\text { Rádkový } \\
\text { součet }\end{array}$} \\
\cline { 2 - 6 } & dvě a více & jedna & žádná & neuvedl & $18(100 \%)$ \\
\hline obec s méně než 3 tisíci obyvatel & $6(33 \%)$ & $1(6 \%)$ & $11(61 \%)$ & & $32(100 \%)$ \\
\hline malé město s 3-15 tisíci obyvatel & $13(41 \%)$ & $9(28 \%)$ & $10(31 \%)$ & & $35(100 \%)$ \\
\hline město s 15-100 tisíci obyvatel & $24(69 \%)$ & $7(20 \%)$ & $4(11 \%)$ & & $13(100 \%)$ \\
\hline $\begin{array}{l}\text { velké město se } 100 \text { tisíci } \\
\text { až 1 milionem obyvatel }\end{array}$ & $10(77 \%)$ & $2(15 \%)$ & $1(7 \%)$ & & $10(100 \%)$ \\
\hline Praha & $8(80 \%)$ & $1(10 \%)$ & $1(10 \%)$ & & 18 \\
\hline neuvedl & & & & 18 & 126 \\
\hline Sloupcový součet & 61 & 20 & 27 & 18 & 18 \\
\hline
\end{tabular}

Poznámka: Cramérovo $V=0,34$

výrazněji konkurenci okolních škol, což je dáno mimo jiné jejich polohou ve větších sídlech. Možná tím ředitelé vyjadřují, že žáci a jejich zákonní zástupci musí v př́ípadě středních škol vždy aktivně vykonat určité rozhodnutí (strukturně daná volba). Interpretace odpovědí ředitelů víceletých gymnázií je do jisté míry problematická, protože není zřejmé, zda hodnotili počet konkurenčních škol pro nižší stupeň, pro vyšší stupeň, anebo celkový počet pro oba stupně gymnázia.

Tabulka 2 uvádí vztah vnímané konkurence a velikosti sídla pro české základní školy ve vzorku PISA 2012. Zajímavé je, že konkurenci jiných škol uvádí i část škol $\mathrm{v}$ nejmenších obcích - nevíme ale, zda ředitelé pocitují konkurenci sousedních základních škol, či víceletých gymnázií. Naopak absence pocitované konkurence u části škol v největších sídlech může naznačovat sebevědomí ředitelů, ale také problematičnost českého znění otázky.

Tabulka 3 ukazuje rozdělení odpovědí ředitelů pouze základních škol na otázku: Jak často jsou prí prijimáni žákĩ do Vaši školy zvažovány studijni výsledky žáka (včetnè výsledku prijímacích zkoušek)? I když na úrovni základních škol většina ředitelů uvádí, že nedochází k výběru žáků školou podle akademických kritérií, tak k selekci žáků dochází nejvíce tam, kde působí konkurence. Abychom mohli zmíněný vztah otestovat, vytvořili jsme sloučenou kategorii „výběr občas nebo vždy" a sloučenou kategorii „jedna a více konkurenčních škol“. V takto upravené tabulce se prokazuje statisticky významně $(p=0,03$, př́loha 2) dvojí tvář fenoménu volby školy i v českých podmínkách - možnost výběru školy rodiči žáka zvyšuje pravděpodobnost výběru žáků školou. 
Tab. 3. Vztah vnímané konkurence lokálních škol a selekce žáků podle výsledků u základních škol ve vzorku PISA (počty škol a sloupcová procenta)

\begin{tabular}{|c|c|c|c|c|c|}
\hline \multirow{2}{*}{ Výběr podle výsledků } & \multicolumn{4}{|c|}{ Počet konkurenčních škol } & \multirow{2}{*}{$\begin{array}{c}\text { Rádkový } \\
\text { součet }\end{array}$} \\
\hline & dvě a více & jedna & žádná & neuvedl & \\
\hline nikdy & $35(57 \%)$ & $13(65 \%)$ & $22(82 \%)$ & & 70 \\
\hline občas & $18(30 \%)$ & $2(10 \%)$ & $2(7 \%)$ & & 22 \\
\hline vždy & $3(5 \%)$ & $3(15 \%)$ & $1(4 \%)$ & & 7 \\
\hline jiná odpověd', neuvedl & $5(8 \%)$ & $2(10 \%)$ & $2(7 \%)$ & 18 & 27 \\
\hline Sloupcový součet & $61(100 \%)$ & $20(100 \%)$ & $27(100 \%)$ & 18 & 126 \\
\hline
\end{tabular}

Poznámka: Cramérovo $V=0,23$

\subsection{Konkurence a výsledky českých žáků}

$\mathrm{V}$ tabulce 4 jsou uvedeny parametry dvouúrovňového modelu, který vysvětluje výsledek v matematickém testu všech patnáctiletých žáků pomocí socioekonomického statusu na úrovni žáka a školy a pomocí vybraných charakteristik školy. Nulový model ukázal, že $44 \%$ rozptylu v matematických výsledcích je možno vysvětlit rozdíly mezi školami. Velikost rozdílů mezi školami, která tradičně patř́ ve srovnání zemí OECD k nejvyšším, je jistě ovlivněna skutečností, že do souboru PISA jsou zařazeny školy poskytující základní i střední vzdělání.

Tabulka obsahuje parametry tří modelů. První model obsahuje všechny nezávislé proměnné a nezohledňuje typ školy, druhý model obsahuje rovněž všechny nezávislé proměnné a zohledňuje typ školy, třetí model obsahuje pouze proměnné, které se prokázaly jako statisticky významné, a zohledňuje typ školy. ${ }^{24}$

Model 1 ukazuje, že konkurence mezi školami se bez zohlednění typu školy skutečně jeví jako faktor, který pozitivně ovlivňuje výsledky žáků. Naše analýza tedy odpovídá výsledkům analýzy zveřejněné $v$ publikaci OECD. Zařadíme-li však do modelu typ školy (referenční úrovní je střední odborné učiliště bez maturity), význam konkurence zmizí. Je tedy zřejmé, že se nejedná o pozitivní dopad konkurence na výsledky žáků, ale o efekt odlišných výsledků žáků jednotlivých typů škol. V posledním modelu jsou zařazeny pouze proměnné, které se prokázaly jako statisticky významné. Kromě typu školy a socioekonomického statusu na úrovni žáka i na úrovni školy (socioekonomické složení žáků dané školy) je to též typ zřizovatele a diferenciace. Veřejné školy dosahují lepších výsledků než školy ostatních zřizovatelů a školy, které

\footnotetext{
${ }^{24}$ Prediktory nejsou centrovány.
} 
Tab. 4. Školní faktory ovlivňující výsledek českých patnáctiletých žáků v matematickém testu

\begin{tabular}{|l|c|c|c|c|c|c|c|c|c|}
\hline & \multicolumn{3}{|c|}{ Model 1 } & \multicolumn{3}{c|}{ Model 2 } & \multicolumn{3}{c|}{ Model 3 } \\
\cline { 2 - 11 } & koef. & s.e. & sig. & koef. & s.e. & sig. & koef. & s.e. & sig. \\
\hline Konstanta & 490,75 & 13,75 & 0,000 & 450,25 & 15,94 & 0,000 & 437,78 & 13,29 & 0,000 \\
\hline escs & 13,93 & 2,31 & 0,000 & 13,92 & 2,31 & 0,000 & 13,92 & 2,31 & 0,000 \\
\hline Velikost & 0,02 & 0,01 & 0,113 & 0,019 & 0,01 & 0,106 & & & \\
\hline SBOR & $-2,45$ & 3,61 & 0,499 & $-2,71$ & 3,26 & 0,408 & & & \\
\hline VEŘEJNÁ & 18,60 & 10,64 & 0,082 & 25,1 & 10,62 & 0,019 & 29,86 & 9,88 & 0,003 \\
\hline KONKURENCE & 21,09 & 8,58 & 0,015 & 7,94 & 9,38 & 0,399 & & & \\
\hline DIFERENCIACE & $-11,07$ & 5,91 & 0,062 & $-11,77$ & 5,22 & 0,025 & $-12,45$ & 5,65 & 0,028 \\
\hline RODIČE & 7,22 & 7,63 & 0,345 & 3,41 & 6,14 & 0,580 & & & \\
\hline ESCS & 113,73 & 9,08 & 0,000 & 60,46 & 12,44 & 0,000 & 54,98 & 11,93 & 0,000 \\
\hline ZŠ & & & & 23,82 & 10,16 & 0,020 & 25,87 & 10,04 & 0,011 \\
\hline VG & & & & 100,87 & 15,83 & 0,000 & 108,46 & 15,47 & 0,000 \\
\hline 4G & & & & 88,47 & 15,03 & 0,000 & 95,23 & 14,15 & 0,000 \\
\hline SOŠ & $-31,7$ & 11,53 & 0,070 & $-14,94$ & 10,55 & 0,160 & & & \\
\hline Nad_3000 & $-18,85$ & 11,76 & 0,110 & $-19,25$ & 10,61 & 0,071 & & & \\
\hline Nad_15000 & $-8,12$ & 8,06 & 0,315 & $-6,28$ & 6,67 & 0,348 & & & \\
\hline Nad_100 000 & 5,81 & 6,63 & 0,382 & 6,52 & 7,65 & 0,396 & & & \\
\hline Praha & & & 55,91 & 10,89 & 0,000 & 57,97 & 10,60 & 0,000 \\
\hline Vysvětlený rozptyl na úrovni školy & $65 \%$ & & & $77 \%$ & & & $76 \%$ \\
\hline
\end{tabular}

uplatňují diferenciaci, dosahují statisticky významně horších výsledků než školy, které ji neuplatňují. Poslední rádek tabulky ukazuje, že poslední model vysvětluje $76 \%$ rozdílů na úrovni školy.

Tabulka 5 ukazuje parametry modelů pouze pro základní školy. $\mathrm{V}$ př́ípadě základních škol je možno vysvětlit rozdíly mezi školami $21 \%$ rozptylu ve výsledcích žáků. Do prvního modelu je opět zařazen na úrovni žáka socioekonomický status a na úrovni školy všechny školní proměnné. Druhý model obsahuje pouze faktory, které se prokázaly jako statisticky významné. Tabulka ukazuje, že stejně jako $\mathrm{v}$ př́padě všech škol vzdělávajících patnáctileté žáky, i v př́ípadě základních škol jsou výsledky ovlivněny socioekonomickým statusem na úrovni žáka i na úrovni školy. Zde se však neprokázal vliv žádné 
z uvedených proměnných s výjimkou velikosti obce, v níž škola působí. To znamená, že se pozitivně neuplatnila ani konkurence, ani diferenciace, ani výběrovost, jako statisticky nevýznamné se však ukázaly rovněž všechny faktory týkající se přístupu rodičů a školy. Poněkud nečekaný je negativní efekt velikosti lokality. Pokud porovnáváme výsledky škol v různých sídlech, se zvětšující se velikostí sídla se výsledky zlepšují. Výsledky našeho modelu naznačují, že se jedná výlučně o efekt různého složení obyvatel a že školy v malých sídlech naopak odvádějí lepší práci.

\section{DisKuSE}

Naše analýza nepotvrdila tvrzení prezentované $\mathrm{v}$ publikaci OECD, že konkurence mezi školami působí pozitivně na výsledky žáků. Poté, co byly do analýzy zahrnuty typy škol, efekt konkurence vymizel. Víceúrovňové modely ovšem potvrdily silný efekt typu střední školy, kde mezi výsledky žáků jednotlivých středoškolských větví standardně shledáváme velké rozdíly i po zohlednění socioekonomického statusu, jehož efekt je rovněž významný (zde se nejedná o nová zjištění,

Tab. 5. Školní faktory ovlivňující výsledek českých patnáctiletých žáků ZŠ v matematickém testu

\begin{tabular}{|l|c|c|c|c|c|c|}
\hline \multirow{2}{*}{} & \multicolumn{3}{|c|}{ Model 1 } & \multicolumn{3}{c|}{ Model 2 } \\
\cline { 2 - 7 } & koef. & s.e. & sig. & koef. & s.e. & sig. \\
\hline konstanta & 516,74 & 18,29 & 0,000 & 503,39 & 4,82 & 0,000 \\
\hline escs & 19,00 & 3,90 & 0,000 & 19,02 & 3,90 & 0,000 \\
\hline VELIKOST & 0,03 & 0,02 & 0,116 & & & \\
\hline SBOR & 5,37 & 4,79 & 0,266 & & & \\
\hline KONKURENCE & 15,22 & 9,00 & 0,094 & & & \\
\hline DIFERENCIACE & $-9,60$ & 7,70 & 0,216 & & & \\
\hline RODICE & $-9,73$ & 10,19 & 0,343 & & & \\
\hline ESCS & 93,29 & 16,05 & 0,000 & 93,06 & 16,51 & 0,000 \\
\hline PROPAGACE & $-0,85$ & 3,00 & 0,777 & & & \\
\hline VYBER & $-7,44$ & 9,55 & 0,438 & & & \\
\hline NAD_3000 & $-25,83$ & 11,99 & 0,034 & & & \\
\hline NAD_15000 & $-16,88$ & 8,64 & 0,054 & & & \\
\hline NAD_1000000 & 19,85 & 9,88 & 0,047 & & & \\
\hline PRAHA & $-40,84$ & 15,10 & 0,009 & $-44,02$ & 15,38 & 0,006 \\
\hline Vysvětlený rozptyl na úrovni školy & & $59 \%$ & & & $52 \%$ \\
\hline
\end{tabular}


pouze se opět potvrzuje výrazná diferenciace českého vzdělávacího systému podle rodinného zázemí žáků). Překvapivý není ani pozitivní efekt veřejných škol. I když v českém vzdělávacím systému existují elitní soukromé střední školy, celkově dosahují veřejné školy lepších výsledků. $\mathrm{Na}$ soukromých středních školách totiž často končí žáci, kteří neuspěli v přijímacím řízení na veřejné školy a jejichž vstupní znalosti jsou tedy horší než $\mathrm{v}$ prrípadě žáků veřejných škol. Efekt diferenciace, který se objevil v souboru patnáctiletých žáků ze všech typů škol, pravděpodobně souvisí se skutečností, že $\mathrm{k}$ diferenciaci dochází častěji v sektoru odborných škol, jejichž žáci mají celkově horší výsledky.

Výsledky analýz provedených na výběrovém souboru všech patnáctiletých žáků jsou negativně poznamenány nesrovnatelností základních a středních škol. Čeští výzkumníci věnovali $\mathrm{v}$ minulosti značnou pozornost zkoumání druhého stupně povinného vzdělávání z pohledu diferenciace mezi základními školami a víceletými gymnázii. Dosud malá pozornost byla věnována diferenciaci mezi samými základními školami. Tady vidíme přínos naší práce.

Pro české základní školy platí, podobně jako tomu je $\mathrm{v}$ mezinárodním průměru, že velká většina $z$ nich pocituje konkurenci okolních škol v soutěži o žáky. Konkurence se dotýká i mnoha škol v nejmenších sídlech (do 3 tisíc obyvatel), což odpovídá zjištěním Simonové (2015a) a Kučerové a kol. (2015), že i rodiče z malých míst často zvažují možnost vozit/posílat dítě do školy do většího města (pokud tam dojižzèjí za prací, ale někdy i nezávisle na tom), pokud se domnívají, že městské školy poskytují efektivnější vzdělání. ${ }^{25}$

$\mathrm{Z}$ toho důvodu jsme provedli analýzu odděleně na výběrovém souboru základních škol. Její výsledky naznačují, že rovněž zde žádný dopad na výsledky žáků nemá ani konkurence, ani proměnná specifikující výběrovost školy. To může být ovšem způsobeno efektem socioekonomického složení žáků, který může být natolik dominantní, že ostatní efekty zastíní. V této souvislosti je zajímavý negativní efekt pražských škol, který je třeba podrobit dalšímu zkoumání.

Analýza neukázala žádný efekt spojený s pedagogickým sborem nebo př́stupem rodičů žáků. To je ovšem velmi pravděpodobně způsobeno tím, jak byly tyto indikátory ve výzkumu PISA operacionalizovány - ve všech př́padech se jedná pouze o subjektivní hodnocení ředitele školy. Obdobně byl pro Českou republiku malý vliv faktorů pedagogického sboru a vnímané podpory rodičů na výsledky žáků zjištěn i v šetření TIMSS a PIRLS 2011 (Martin et al., 2013; Mullis et al., 2012; Dvořák, 2015).

Pokud jde o naši ústřední otázku, kterou byl vliv soutěže na výsledky škol, po zohlednění existence různých typů škol se situace $\mathrm{v}$ České republice neliší od výsledků typických pro soubor zemí

\footnotetext{
${ }^{25}$ Podle Kučerové a kol. (2015) existuje naopak skupina rodičů, kteří na základě svých kritérií cíleně preferují pro své děti malé, obvykle venkovské školy kvůli menším počtům dětí ve třídě. Data v tabulce 5 naznačují, že to může mít určitý podklad i v oblasti akademických výsledkủ (zde v př́padě druhého stupně základních škol).
} 
účastnících se šetření PISA. Fungování mechanismu konkurence v Česku, které by bylo odlišné od ostatních sledovaných zemí, se zdá nepravděpodobné. Ostatně Ball a Maroy (2009) v mezinárodní srovnávací studii zjistili, že jednání škol na lokálním trhu se $\mathrm{v}$ různých zemích řídí velmi podobnou logikou navzdory tomu, že se národní rámce liší v nastavení podmínek pro rodičovskou volbu a mechanismů soutěže škol. Soutěž mezi základními školami v určitém místě sama o sobě nevede $\mathrm{k}$ lepším výsledkům žáků $\mathrm{z}$ této lokality $\mathrm{v}$ matematice. Jistě $\mathrm{k}$ tomu přispívá, že i čeští rodiče podobně jako jinde upřednostňují př̀i výběru jiná kritéria než kvalitu vyučování základních předmětů (Simonová, 2015a). Určitou potíž při interpretaci představuje formulace otázky na soutěž mezi školami (viz pozn. 16), resp. její překlad do češtiny. Nevíme, zda u základních škol při jejím zodpovídání ředitelé brali $\mathrm{v}$ úvahu konkurenci víceletých gymnázií, která se teoreticky vzato týká každé školy (ale regionálně se její míra liší).

Absence dopadu konkurence na výsledky žáků je v souladu se zjištěním rovněž vyplývajícím z dat PISA 2012, že vedení českých škol se dnes $\mathrm{v}$ průměru víc zaměřuje na budování vnějšího obrazu školy, resp. na předcházení problémům a jejich řešení (což patř́i k péči o prestiž školy) než na kvalitu vyučování. Také v blízkém Rakousku tržní mechanismy sice vybudily aktivitu škol navenek (směřující $\mathrm{k}$ rodičům a dalším aktérům), ale menší péče je věnována kvalitě procesů uvnitř škol a tř́íd (Altrichter et al., 2014, s. 679).
Domníváme se, že skutečnosti uvedené v tomto článku mají významné důsledky pro vzdělávací politiku. Přes dynamický nárůst počtu žáků ve školách s nestátním, zejména soukromým zřizovatelem nadále naprostá většina českých dětí získává základní vzdělání ve veřejných školách. Mechanismus soutěže o žáky mezi veřejnými školami spojený s incentivou financování $\mathrm{z}$ řady důvodů $\mathrm{v}$ Česku (tak jako jinde) nefunguje tak, jak si zastánci trhu představují. Mohou ovšem existovat príznivé efekty, které nejsou předmětem našeho hodnocení (napríiklad v oblasti sociálního klimatu školy). Soutěž mezi školami však nevede $\mathrm{k}$ lepším výsledkům žáků $\mathrm{v}$ matematice jako základní dovednosti, jejíž význam jako součásti všeobecné gramotnosti i nutné součásti př́rodovědného a technické vzdělání se začíná i u nás znovu doceňovat. $Z$ literatury rovněž víme, že ani existence elitních či jiných alternativních škol v systému, at' už veřejných, nebo nestátních, nezpůsobí sama o sobě (např́klad šířením dobré praxe) zásadní zvýšení efektivity běžných škol. Navíc dočasně příznivá demografická situace působení tržních pobídek dále oslabuje (Dvořák et al., 2015a; Kučerová , 2015).

O českém způsobu zavedení trhu ve vzdělávání asi platí to, co se vytýká i české cestě k tržní ekonomice vůbec. K liberalizaci a poskytnutí široké autonomie došlo při absenci jasných pravidel a funkčních institucí. K negativním důsledkům marketizace vzdělávání v České republice může patřit i zaměření školských manažerů převážně na vnější propagaci školy místo na její vnitřní pedagogický rozvoj. 
Neviditelná ruka trhu sama o sobě nedokáže překonat negativní dopady nekoncepčnosti a nestability české vzdělávací politiky i zjevné neschopnosti jejích aktérů (Veselý, 2015) a malé kapacity podpůrného systému vzdělávání. Zahraniční zkušenosti ukazují, že za určitých specifických podmínek rodičovská volba a soutěž mezi školami mohou přinášet převažující pozitivní efekty, avšak vyžaduje to kvalitní nastavení dalších institucionálních podmínek včetně předcházení negativním efektům, k nimž patř́ rozvoj segregace některých skupin žáků.

\section{ZÁVĚR}

$\mathrm{V}$ textu diskutujeme limity analýz vzdělávací politiky prováděných $\mathrm{OECD}$. Víceúrovňové modely ukázaly neúplnou interpretaci dopadu konkurence mezi školami na výsledky žákủ v České republice ze strany autorů mezinárodní zprávy PISA 2012 (OECD, 2013). Nenašli jsme lepší (ani horší) výsledky v matematice tam, kde jsou základní školy mezi sebou vystaveny větší konkurenci. Jiné případné pozitivní či negativní efekty konkurence nebyly předmětem zkoumání.
Závěrem by neměla být skepse $\mathrm{k}$ šetření PISA jako takovému, ale výzva k zapojení širšího okruhu aktérů do jejich analýz a interpretací. Dosavadní rozporné výsledky výzkumů efektů tržních mechanismů jako nástroje vzdělávací politiky vedou $\mathrm{v}$ zahraničí jednak $\mathrm{k}$ dalším výzkumům (např. zaměřeným na dokončování školy jako hlavní závislou proměnnou), ale $\mathrm{i} k$ hledání alternativních mechanismů zlepšení práce škol i výsledků všech žáků. Kromě již zmíněné akontability to může být rozvíjení jiných možností, jimiž by rodiče a žáci mohli účinně vyjádřit (voice) svou př́padnou nespokojenost s kvalitou školami poskytovaných služeb, než je odchod do konkurenční školy (exit) či mimo veřejný vzdělávací systém (Jacobsen, 2008). Na straně škol je to pak nejen soutěž, ale i spolupráce škol (Chapman, 2014; Chapman \& Muijs, 2014) a tzv. systémové vedení (systemic leadership). Existují i země (např. vlámská komunita v Belgii), které v poslední době omezují volbu školy a uplatňují při umístování žáků do škol centrální regulaci, nebo potenciálně konkurenční školy slučují (OECD, 2013, s. 133).

\section{LiTERATURA}

Adnett, N., \& Davies, P. (2000). Competition and curriculum diversity in local schooling markets: theory and evidence. Journal of Educational Policy, 15(2), 157-167.

Altrichter, H., Bacher, J., Beham-Rabanser, M., Nagy, G., \& Wetzelhütter, D. (2011). The effects of a free school choice policy on parents's school choice behaviour. Studies in Educational Evaluation, 37(4), 230-238.

Altrichter, H., Heinrich, M., \& Soukup-Altrichter, K. (2014). School decentralization as a process of differentiation, hierarchization and selection. Journal of Education Policy, 29(5), 675-699. 
Ball, S. (2008). New philanthropy, new networks and new governance in education. Political Studies, 56, 747-765.

Ball, S. J., \& Maroy, C. (2009). School's logics of action as mediation and compromise between internal dynamics and external constraints and pressures. Compare: A Journal of Comparative and International Education, 39(1), 99-112.

Berends, M. (2015). Sociology and school choice: What we know after two decades of charter schools. Annual Review of Sociology, 41, 159-180.

Bruns, B., Filmer, D., \& Petrinos, H. A. (2011). Making schools work. New evidence on accountability reforms. Washington, D.C.: World Bank.

Dvořák, D. (2007). Nezávislé náboženské vzdělávání za „normalizace“. Soudobé dějiny, 14(2-3), 449-470.

Dvořák, D. (2015). Důraz školy na akademický úspěch: TIMSS 2011 jako sonda do reformy v České republice. Pedagogická orientace, 25(4), 583-604.

Dvořák, D., Starý, K., \& Urbánek, P. (2014). High autonomy and low accountability: Case study of five Czech schools. Pedagogická orientace, 24(6), 919-940.

Dvořák, D., Starý, K., \& Urbánek, P. (2015a). Škola v globálni době: Proměny péti českých základnich škol. Praha: Karolinum.

Dvořák, D., Starý, K., \& Urbánek, P. (2015b). Malá škola po pěti letech: proměny školy v době reformy. Pedagogická orientace, 25(1), 9-91.

Gibbons, S., Machin, S., \& Silva, O. (2008). Choice, competition and pupil achievement. Journal of the European Economic Association, 6(4), 912-947.

Gillies, J. (Ed.). (2010). The power of persistence: Education system reform and aid effectiveness. Washington, DC: USAID/Equip 2.

Hess, F. M. (2009). A market for knowledge? In G. Sykes, B. Schneider \& D. N. Plank (Eds.), Handbook on education policy research (s. 502-512). New York: AERA \& Routledge.

Chapman, Ch. (2014). From within- to between- and beyond-school improvement: A case of rethinking roles and relationships? International Council for School Effectiveness and Improvement Monograph Series 3. Springwood: ICSEI.

Chapman, Ch., \& Muijs, D. (2014). Does school-to-school collaboration promote school improvement? A study of the impact of school federations on student outcomes. School Effectiveness and School Improvement, 25(3), 351-393.

Jacobsen, R. (2008). The voice of the people in education policy. In G. Sykes, B. Schneider \& D. N. Plank (Eds.), Handbook on education policy research (s. 307-318). New York: AERA \& Routledge.

Jennings, J. L. (2010). School choice or schools' choice? Managing in an era of accountability. Sociology of Education, 83(3), 227-247.

Ježková, V., Dvořák, D., \& Chapman, Ch. (2010). Školní vzděláváni ve Velké Británii. Praha: Karolinum.

Kašparová, I., \& Souralová, A. (2014). „Od lokální k cikánské škole“: homogenizace školní třídy a měnící se role učitele. Orbis Scholae, 8(1), 79-96. 
Kučerová, S. (2012). Proměny územni struktury základniho školství v Česku. Praha: Česká geografická společnost.

Kučerová, S. R., Bláha, J. D., \& Pavlasová, Z. (2015). Malé venkovské školy na trhu se základním vzděláváním: Jejich působnost a marketing na př́kladu Turnovska. Sociologický casopis / Czech Sociological Review 51(4), 607-636.

Martin, M. O., Foy, P., Mullis, I. V. S., \& O’Dwyer, L. M. (2013). Effective schools in reading, mathematics, and science at the fourth grade. In M. O. Martin \& I. V. S. Mullis (Eds.), TIMSS and PIRLS 2011: Relationships among reading, mathematics, and science achievement at the fourth grade-implications for early learning (s. 109-178). Chestnut Hill, MA: TIMSS \& PIRLS International Study Center, Boston College.

Mullis, I. V. S., Martin, M. O., Foy, P., \& Arora, A. (2012). TIMSS 2011 international results in mathematics. Chestnut Hill: TIMSS \& PIRLS International Study Center, Boston College.

Nekorjak, M., Souralová, A., \& Vomastková, K. (2011). Uvíznutí v marginalitě: vzdělávací trh, „romské školy“ a reprodukce sociálně prostorových nerovností. Sociologický časopis, 47(4), 657-680.

OECD. (2013). PISA 2012 Results: What makes schools successful (Volume IV): Resources, policies and practices. Paris: OECD Publishing.

OECD. (2014a). Education at a Glance 2014: OECD Indicators. OECD Publishing.

OECD. (2014b). When is competition between schools beneficial? PISA in Focus, 42 (August).

OECD. (2015). How have schools changed over the past decade? PISA in Focus, 52 (June).

Póder, K., \& Kerem, K. (2012). School choice and educational returns in the EU: With a focus on Finland and Estonia. Baltic Journal of European Studes, 2(2), 65-86.

Rabušicová, M., \& Pol, M. (1996a). Vztahy školy a rodiny dnes: hledání cest k partnerství (1). Pedagogika, 46(1), 49-61.

Rabušicová, M., \& Pol, M. (1996b). Vztahy školy a rodiny dnes: hledání cest k partnerství (2). Pedagogika, 46(2), 105-116.

Rabušicová, M., Trnková, K., Šed’ová, K., \& Čiháček, V. (2003). O školách, v nichž jsou rodiče i ředitelé spokojeni se vzájemnou spoluprací. Sborník prací Filozofické fakulty Brněnské univerzity, U 8, 103-116.

Simonová, J. (2015a). Postoje rodičů k volbě základní školy. Studia paedagogica, 20(3), 69-88.

Simonová, J. (2015b). Volba školy v primárním vzdélávání jako dũležitý mechanismus ovlivňujicí spravedlivý prístup ke vzdèlávání. (Doktorská disertace). Dostupné z https://is.cuni.cz/ webapps/zzp (133185).

Soukup, P. (2006). Proč užívat hierarchické lineární modely? Sociologický časopis / Czech Sociological Review, 42(5), 987-1012.

Straková, J., \& Simonová, J. (2015). Výběr základní školy v ČR a faktory, které jej ovlivňují. Sociologický ćasopis, 51(4), 587-606.

Veselý, A. (2015). Národní rada pro vzdělávání 1994-2014: Geneze záměru a př́činy jeho neuskutečnění. Orbis scholae, 9(1), 11-28. 
Walford, G. (1996). School choice and the quasi-market in England and Wales. Oxford Studies in Comparative Education, 6(1), 49-62.

Waitoller F. R., \& Thorius, K. K. (2015). Playing hopscotch in inclusive education reform: examining promises and limitations of policy and practice in the US. Support for Learning, 30(1) 23-41.

West, M. (2009). Public choice and the political economy of American education. In G. Sykes, B. Schneider \& D. N. Plank (Eds.), Handbook on education policy research (s. 362-371). New York: AERA \& Routledge.

West, M. R., \& Peterson, P. E. (2006). The efficacy of choice threats within accountability systems: Results from legislatively induced experiments. The Economic Journal, 116(March) C46-C62.

van Zanten, A. (2005). New modes of reproducing social inequality in education: The changing role of parents, teachers, schools and educational policies. European Educational Research Journal, 4(3), 155-169.

van Zanten, A. (2009). Competitive arenas and schools' logics of action: A European comparison. Compare, 39(1), 85-98.

RNDr. Dominik Dvořák, Ph.D.,

Univerzita Karlova v Praze, Pedagogická fakulta, Ústav výzkumu a rozvoje vzdèlávání;

e-mail:dominik.dvorak@pedf.cuni.cz

RNDr. Jana Straková, Ph.D.,

Univerzita Karlova v Praze, Pedagogická fakulta, Ústav výzkumu a rozvoje vzdèlávání;

e-mail: jana.straková@pedf.cuni.cz 
DVOŘ́K, D., STRAKOVÁ, J. School Competition and Pupil Achievement in the Czech Republic: A Close Look at the PISA 2012 Study

Several studies have shown that market-based reforms of education generally fail to improve the pupil performance across or within national school systems. On the other hand, the PISA 2012 survey found, however, that in the Czech Republic schools that compete with other neighbouring schools for pupils tend to perform better in mathematics even after accounting for the socio-economic and demographic background of pupils and for relevant school characteristics $(O E C D, 2013)$. In our study, we re-evaluate this result. The impact of school variables on student achievement was studied using the PISA datasets and two-level models with pupils at the first level and schools at the second level. After we took into account the different types of secondary schools in the Czech school sample, the apparent positive effect of school competition disappeared.

Keywords: school choice, school competition, achievement, mathematics, Czech Republic, PISA.

Př́loha 1. Vliv změny skóre míry soutěže mezi školami na výsledky v matematice dle regresního modelu PISA (po očištění dalších charakteristik žáků a škol) - zvýrazněné hodnoty jsou statisticky významné (zdroj: OECD, 2013, tabulka IV.1.12c)

\begin{tabular}{|l|c|c|c|c|c|}
\hline & $\begin{array}{c}\text { Změna } \\
\text { skóre }\end{array}$ & s.e. & & $\begin{array}{c}\text { Změna } \\
\text { skóre }\end{array}$ & s.e. \\
\hline Členové OECD & & & Ostatní & & \\
\hline Česko & $\mathbf{2 1 , 6}$ & $(7,9)$ & Hongkong (Č́́na) & 23,2 & $(27,9)$ \\
\hline Nizozemsko & 12,1 & $(9,2)$ & Singapur & 12,2 & $(16,4)$ \\
\hline Izrael & 9,3 & $(5,3)$ & Srbsko & 9,1 & $(9,4)$ \\
\hline Estonsko & $\mathbf{9 , 2}$ & $(4,4)$ & Katar & 8,1 & $(6,8)$ \\
\hline Dánsko & 8,6 & $(5,5)$ & Uruguay & 6,5 & $(3,9)$ \\
\hline Mad’arsko & 7,0 & $(5,6)$ & Argentina & 5,3 & $(6,4)$ \\
\hline Řecko & 4,8 & $(5,9)$ & Albánie & 4,3 & $(5,1)$ \\
\hline Slovinsko & 3,7 & $(4,8)$ & Peru & 4,1 & $(4,7)$ \\
\hline
\end{tabular}




\begin{tabular}{|l|c|c|c|c|c|}
\hline Korea & 2,8 & $(7,9)$ & Kypr & 2,9 & $(4,9)$ \\
\hline Španělsko & 2,5 & $(4,2)$ & Kostarika & 2,4 & $(4,8)$ \\
\hline Chile & 2,0 & $(4,9)$ & Thajsko & 2,3 & $(7,5)$ \\
\hline Turecko & 1,9 & $(6,5)$ & Šanghaj (Č́na) & 1,6 & $(6,2)$ \\
\hline Belgie & 1,8 & $(7,7)$ & Brazílie & 0,3 & $(3,2)$ \\
\hline Norsko & 1,7 & $(4,7)$ & Rusko & $-0,7$ & $(7,2)$ \\
\hline Finsko & 1,1 & $(2,9)$ & Jordánsko & $-2,0$ & $(5,0)$ \\
\hline Itálie & 1,1 & $(2,8)$ & Vietnam & $-2,8$ & $(6,4)$ \\
\hline Kanada & 1,1 & $(3,6)$ & Chorvatsko & $-3,2$ & $(4,6)$ \\
\hline Polsko & 0,9 & $(5,4)$ & Tunisko & $-3,2$ & $(6,1)$ \\
\hline Portugalsko & 0,1 & $(5,5)$ & Kolumbie & $-3,6$ & $(5,9)$ \\
\hline Francie & 0,0 & $(4,4)$ & Malajsie & $-4,1$ & $(5,0)$ \\
\hline Průměr OECD & $-0,2$ & $(1,0)$ & Bulharsko & $-6,5$ & $(7,0)$ \\
\hline Německo & $-0,2$ & $(6,0)$ & Kazachstán & $-6,9$ & $(6,5)$ \\
\hline Mexiko & $-3,6$ & $(3,3)$ & Spoj. arab. emiráty & $-7,8$ & $(5,4)$ \\
\hline Island & $-4,6$ & $(5,9)$ & Tchajwan & $-8,2$ & $(11,0)$ \\
\hline Rakousko & $-4,7$ & $(5,2)$ & Rumunsko & $-8,6$ & $(4,8)$ \\
\hline Irsko & $-5,6$ & $(4,4)$ & Indonésie & $-9,3$ & $(25,3)$ \\
\hline Švédsko & $-5,9$ & $(5,7)$ & Litva & $-13,2$ & $(5,2)$ \\
\hline Švýcarsko & $-7,0$ & $(4,0)$ & Lotyšsko & $-24,4$ & $(6,3)$ \\
\hline UK & $-8,9$ & $(7,5)$ & & & \\
\hline Slovensko & $-9,0$ & $(7,2)$ & & & \\
\hline USA & $-10,5$ & $(5,9)$ & & & \\
\hline Austrálie & $-12,2$ & $(8,2)$ & & & \\
\hline Japonsko & $-13,2$ & $(7,9)$ & & & \\
\hline Nový Zéland & $-13,7$ & $(6,3)$ & & & \\
\hline
\end{tabular}

Př́loha 2. Kontingenční tabulka pro vztah míry konkurence a selektivity u základních škol

\begin{tabular}{|l|c|c|c|}
\hline & \multicolumn{2}{|c|}{ Konkurenční škola v dané lokalitě } & Rádkový součet \\
\hline Výběr žáků podle výsledků & jedna a více & žádná & \\
\hline nikdy & $48 / 52,32$ & $22 / 17,68$ & 70 \\
\hline občas nebo vždy & $26 / 21,68$ & $3 / 7,32$ & 29 \\
\hline Sloupcový součet & 74 & 25 & 99 \\
\hline
\end{tabular}

Poznámka: $C h i^{2}=4,83$, stup. vol. $=1, p=0,028$, Cramérovo $V=0,22$ 
Příloha 3. Korelační matice proměnných zahrnutých do analýzy

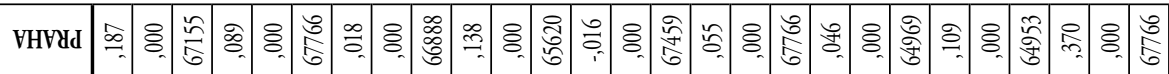

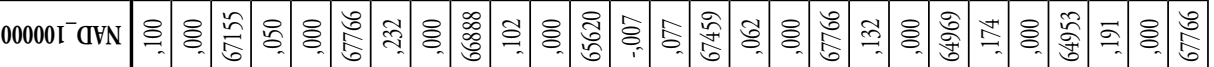

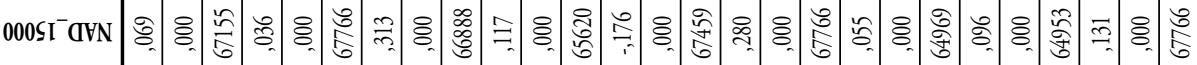
$000 \mathcal{E}^{-}$dVN

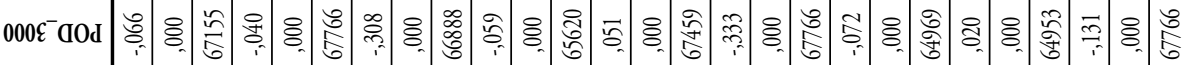

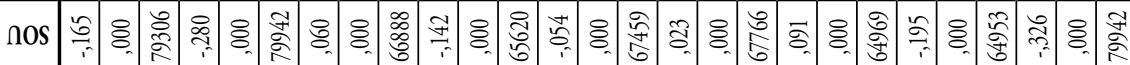

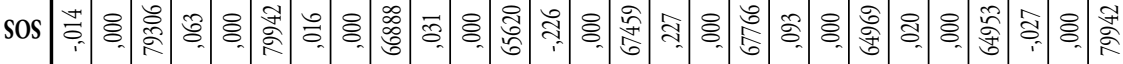

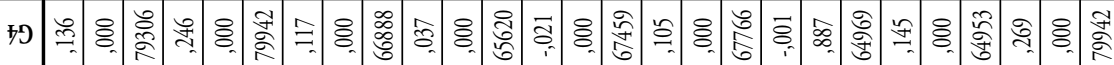

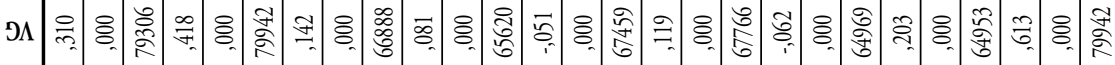

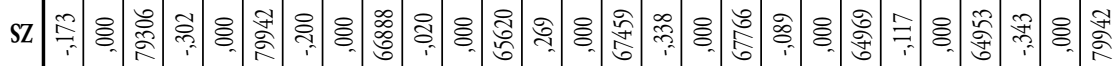
YS STS

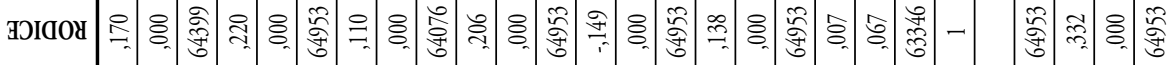
AJHIJNA4AнIव

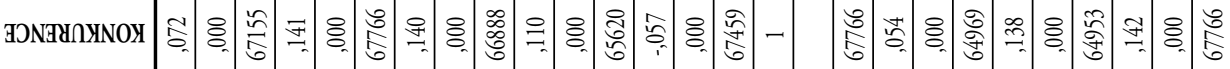

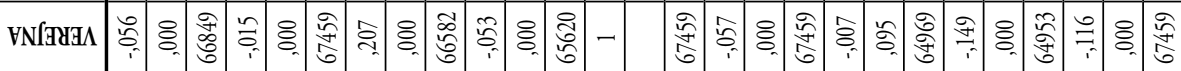
y095 Бे

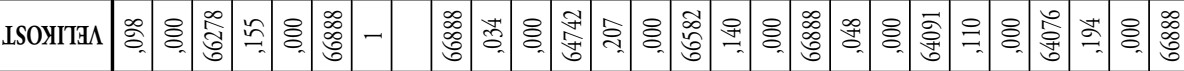

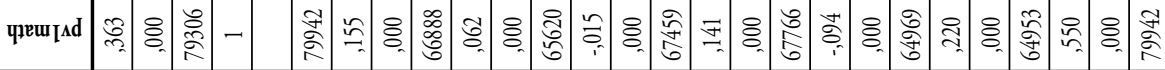
sэг - $\quad$ 命

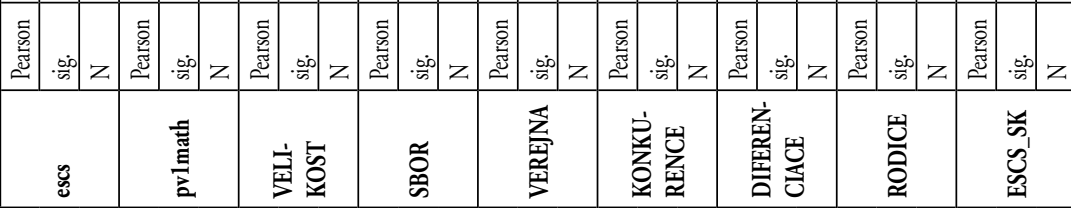




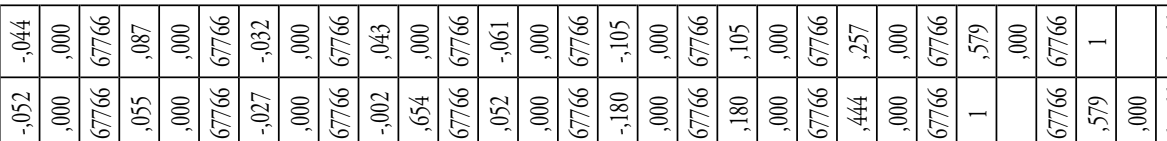
$\rightarrow$ \&

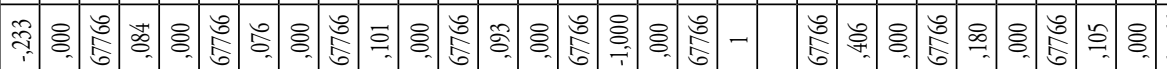

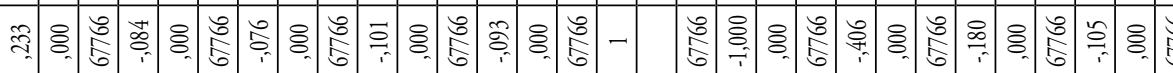

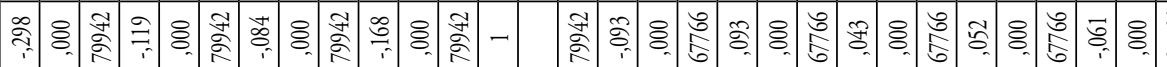

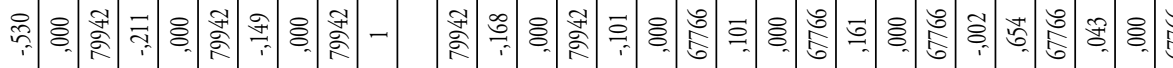

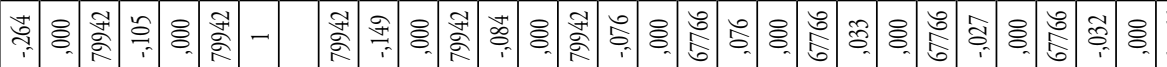

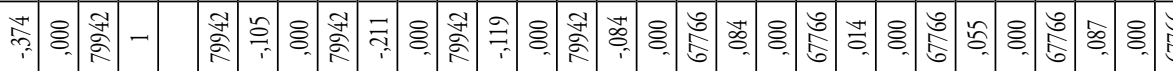

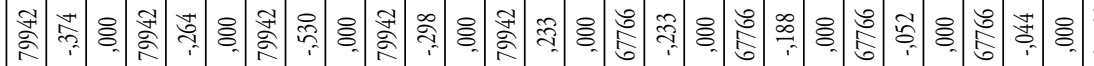

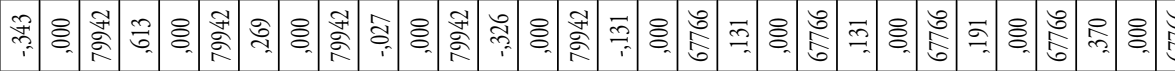

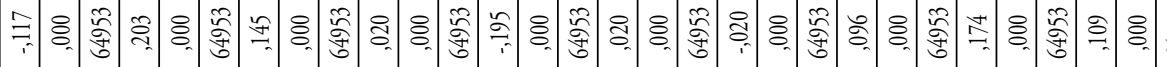

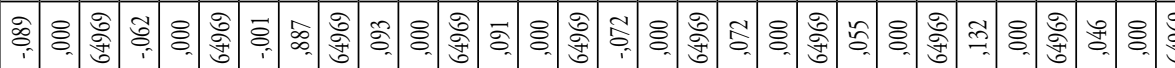

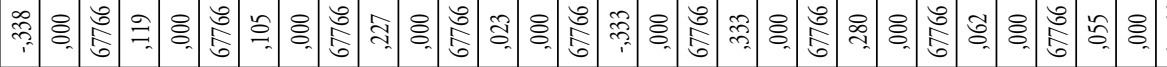

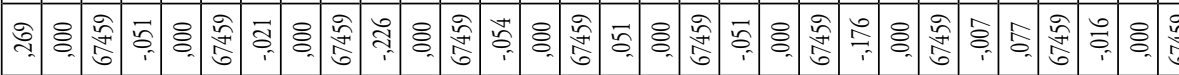

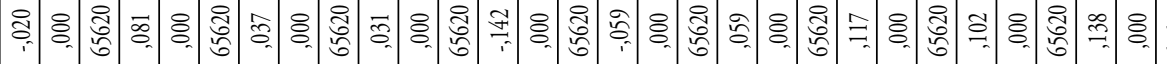
\&:

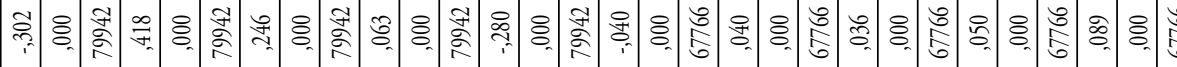

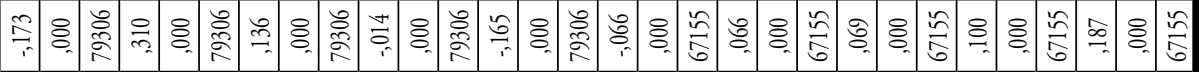

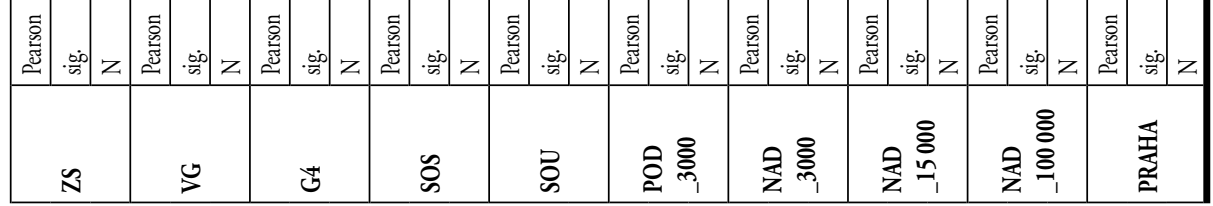

